\title{
Topo-bathymetric and oceanographic datasets for coastal flooding risk assessment: French Flooding Prevention Action Program of Saint-Malo
}

\author{
Léo Seyfried ${ }^{1}$, Laurie Biscara ${ }^{2}$, Fabien Leckler ${ }^{2}$, Audrey Pasquet ${ }^{1}$, and Héloise Michaud ${ }^{1}$ \\ ${ }^{1}$ Shom, 42 Avenue Gaspard Coriolis, BP 45017 - 31032 Toulouse CEDEX 5, France \\ ${ }^{2}$ Shom, 13 rue du Chatellier, 29200 Brest, France \\ Correspondence: Héloise Michaud : heloise.michaud@shom.fr
}

\begin{abstract}
The French Flooding Prevention Action Program of Saint-Malo requires assessment of coastal flooding risks. The first prerequisite is a knowledge of the topography and bathymetry of the bay of Saint-Malo. In addition to existing topobathymetric data, the acquisition of new multibeam bathymetric data is performed. The combination of these datasets allows the generation of two high resolution topo-bathymetric digital terrain models. Then, to understand the hydrodynamic conditions which cause coastal flooding, a dense and extensive oceanographic field experiment is conducted. Oceanographic data were acquired using a network of 22 moorings with 37 sensors, during winter 2018-2019. The network included 2 directional buoys, 2 pressure tide gauges, 18 wave pressure gauges, 4 single-point current meters, 7 current profilers and 4 acoustic wave-current profilers from mid-depth $(25 \mathrm{~m})$ up to the upper beach and the dike system. The oceanographic dataset provides an overview of hydrodynamics in Saint-Malo bay and wave processes leading to coastal flooding. The combination of high-resolution topo-bathymetric and oceanographic datasets provides a unique capability for model validation and process studies. The topo-bathymetric and oceanographic datasets are available freely at doi : https://doi.org/10.17183/MNT_ COTIER_GNB_PAPI_SM_20m_WGS84, https://doi.org/10.17183/MNT_COTIER_PORT_SM_PAPI_SM_5m_WGS84 and https://doi.org/10.17183/CAMPAGNE_OCEANO_STMALO.
\end{abstract}

\section{Introduction}

\subsection{Background}

The constant increase in the concentration of people and economic activity in areas at risk of coastal flooding is problematic, especially in the context of global warming, one of the effects of which is the sea level rise. Thus, public policies need to rely on scientific studies on coastal flooding risk in order to make the most relevant decisions on urban planning or safety.

In France, since the major coastal flooding caused by the storm Xynthia (Bertin et al., 2012), the government has strengthened policies to prevent the risk of coastal flooding. Shom (a public administrative institution supervised by the Ministry of the Armed Forces) develops, in collaboration with the French meteorological service Météo-France, the operational warning system for storm surges, in the scope of HOMONIM project (Jourdan et al., 2020). At the local scale, some initiatives have 
https://doi.org/10.5194/essd-2021-316

Preprint. Discussion started: 1 October 2021

(c) Author(s) 2021. CC BY 4.0 License.

(c) (i)

also been carried out through the French Flooding Prevention Action Programs (PAPI). Thus, to increase scientific knowledge and public recognition of the coastal flooding hazard, Saint-Malo urban area (SMA) has established a preliminary PAPI, in which the Shom participates, as a national expert in support of public policies for the sea and the coasts. This PAPI requires, as a first step, a collection of topo-bathymetric and oceanographic data.

Detailed and accessible topo-bathymetric data is a priority for communities anticipating impacts and preparing strategies in response to coastal risks. This need has increased in recent years and will continue to increase in the near future because elevation data are critical to depict regions prone to climate change impacts. As a result, building high resolution and up-to-date Topo-Bathymetric Digital Terrain Models (TBDTMs) combining very dense and recent measurements from both ship-mounted multibeam echosounder and airborne LIDAR (Light Detection and Ranging), has become a prerequisite for modeling and forecasting of hydrodynamic processes at local scale (Eakins and Taylor, 2010). Shom developed multi-scales DTMs along the metropolitan and overseas French coasts based on user's requirements (Biscara et al., 2016) and on previous works (Eakins and Taylor, 2010; Eakins and Taylor, 2011; Eakins and Grothe, 2014). This nested products line was intended to be implemented in coastal flooding forecast systems in the scope of HOMONIM (Jourdan et al., 2020) and TANDEM (Hébert et al., 2014; Maspataud et al., 2015) projects. However, their diffusion on Shom's data portal facilitated their use for many other marine environment issues (e.g., Furgerot et al., 2019; Tawil et al., 2019; Famin et al., 2020; Tew-Kai et al., 2020).

Monitoring and understanding coastal flooding hazards is achieved by acquiring oceanographic data that are linked to the water level variation on the coast (Melet et al., 2020). In fact, the water level variation is due to a complex combination of processes in the open ocean (linked to the climate changes or the general ocean circulation) and in the coastal zone that will be discussed here. In the coastal zone, the water level variation is mainly caused by tides, storm surge, wave setup, swash, infragravity wave, and also more locally river runoffs, seiches and meteotsunamis (Woodworth et al., 2019; Dodet et al., 2019). Thus, assessing the flooding risk at local scale requires the monitoring of several meteocean variables (water levels, currents and sea states) and quantifying some processes (like storm surge, offshore wave, wave set-up, infragravity wave, swach). Such monitoring requires the establishment of extensive oceanographic campaigns to evaluate and quantify the various processes which cause the floodings. Shom conducts numerous oceanographic campaigns for coastal areas monitoring (Ardhuin, 2010; Filipot et al., 2013; Dodet et al., 2018). Furthermore, Shom is responsible for water level observations along the French coast through tide gauge observation reference network (French designation REFMAR).

\subsection{Field site}

50 Saint-Malo bay is located in the southern part of the Norman-Breton gulf (Figure 1.a). This bay is subjected to semidiurnal mega-tidal regime (maximum tidal range of about $13 \mathrm{~m}$, Shom 2015) and the estuarine conditions are modified by a tidal power plant (Cochet and Lambert 2017). Tidal currents are oriented E-SE to the flow and W-NW to the ebb, the velocities ranging from a few meters per second in the bay to several meters per second in the estuarine part (Dagorne, 1966, 1968). In most of the situations, the waves come from W-NW to N-NW directions, with significant wave heights of up to $6 \mathrm{~m}$ offshore during winter storms. The complex propagation of the waves in the bay due to the presence of numerous obstacles (islets, shoals, groins) limits understanding of hydrodynamics in the bay (Ducatez et al., 2018). Moreover, geomorphology is marked by the presence 


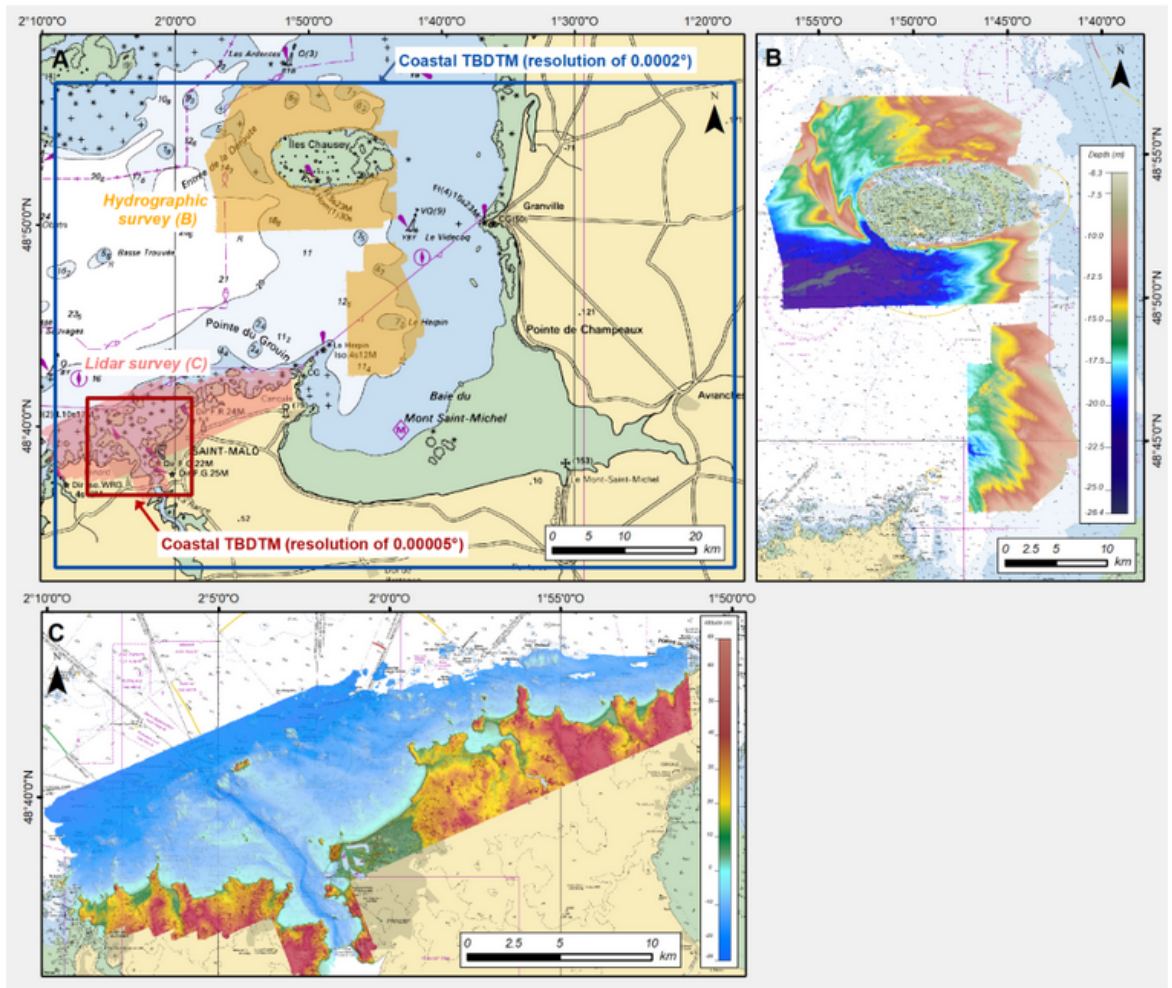

Figure 1. Nautical chart of Saint-Malo harbor and its surroundings (@Shom). (A) Locations of TBDTMs generated in the scope of SaintMalo's PAPI project, (B) Hydrographic surveys carried out in the scope of PAPI Saint-Malo's project, (C) : Bathymetric coverage of Brittany v.20190831 Litto3D® maritime product of Saint-Malo harbor and its surroundings.

of sand and rocky areas in the shallow bay, and a mixture of gravel and pebbles offshore (Bonnot-Courtois et al. 2002) making the dissipation of the wave by bottom friction non-homogeneous in the bay.

The meteorological conditions are characterized by the passage of low pressure systems and cold fronts (Gaspar et al. 2007).

These weather conditions generate storm surges and significant wave fields. Combined with high spring tides, these events can lead to coastal flooding (Cariolet et al. 2010). Despite an existing dike system in front of Saint-Malo (Bonnot-Courtois and Lafond, 1994), eight coastal flooding events have been recorded in the literature between 1979 and 2019, and more than 40 have been identified since 1703 (PPRSM Saint-Malo 2016).

To improve the knowledge of coastal flooding risks in Saint-Malo bay, an extensive bathymetric and oceanographic campaign was performed in winter 2018-2019. These campaigns allowed the creation of topo-bathymetric and oceanographic datasets. The topo-bathymetric and oceanographic datasets were detailed in parts 2 and 3, respectively. The part 4 shows an overview of oceanographic observations available in datasets for coastal flooding assessment. The part 5 provides the datasets availability. Finally, part 6 gives conclusions and limitations of datasets. 
https://doi.org/10.5194/essd-2021-316

Preprint. Discussion started: 1 October 2021

(c) Author(s) 2021. CC BY 4.0 License.

(c) (i)

\section{Topo-bathymetric dataset}

The purpose of the following sections is to present the different data used for the generation of the TBDTMs (Figure 1.a), the most common problems experienced with combining data and the approach adopted by Shom for their resolution (Maspataud et al., 2015; Biscara et al., 2016).

\subsection{Data sources}

\subsubsection{Specific Hydrographic Surveys}

Scope of the PAPI, the hydrographic vessels La Pérouse, Laplace and Borda were deployed between 2018 and 2019 in the Normand-Breton Gulf in order to update areas characterized by poor hydrographic knowledge. The hydrographic surveys covered approximately $230 \mathrm{~km}^{2}$ in water depths ranging from $-30 \mathrm{~m}$ to $+6 \mathrm{~m}$ relative to the local chart datum (Figure 1.b). The hydrographic vessels are equipped with a Kongsberg-Maritime EM710 multibeam echo sounder associated with the SIS acquisition system. Depending on the vessel, sound velocity profiles were measured using Sippican XBT probes or a Valeport SVP1000 Sound Velocity Profiler to correct bathymetric data for local variations in sound speed. Real time GPS positioning was collected with the Applanix POS MV inertial unit. Positioning data were post processed in POSPac software using global navigation satellite systems (GNSS) solutions. Horizontal positions were referenced to WGS84 or ITRF2014 geodetic systems at the time of the survey.

All the bathymetric data acquired were processed with the CARIS HIPS version 9.1 software. Tidal corrections were made based on the data from the tidal reference station of Saint-Malo and additional tide gauges specifically deployed for the surveys. The soundings were vertically referenced to the chart datum of Saint-Malo. Subset editing was carried out to remove systematic errors and outliers. Processed and cleaned data were subjected to final validation by a qualified hydrographer.

\subsubsection{Litto3D® program}

LIDAR surveys exploited in this study were carried out within the framework of Litto3D® program. This national program is based on a partnership between Shom and the French National Geographic Institute (IGN) (Louvart and Grateau, 2005). It aims to provide very high resolution coastal altimetric models of metropolitan and overseas French coasts (Pastol, 2011). Litto3D® surveys are regularly implemented on Shom's data portal (data.shom.fr) under Open Licence.

Coastal mapping of the Normand-Breton Gulf was performed by Shom's Litto3D® team between 2016 and 2018, covering approximatively $700 \mathrm{~km} 2$ and reaching up to $18 \mathrm{~m}$ water depth (Figure 1.c). Topo-bathymetric data were acquired from a Cessna Grand Caravan 208B type aircraft equipped with an airborne lidar topo-bathymetric HawkEye III double hatch (Leica Geosystems). The data were acquired in relation to the ellipsoid and referenced horizontally with respect to the RGF93 in standard UTM $30 \mathrm{~N}$ projection. The trajectory of the aircraft was based on the GNSS system and processed by Inertial Explorer. The trajectory data were post-processed using the stations of the RBF (Réseau de Base Français). The points were generated from the processed waveform with Lidar Survey Studio (LSS) and the point cloud was processed using PFMABE version 
https://doi.org/10.5194/essd-2021-316

Preprint. Discussion started: 1 October 2021

(c) Author(s) 2021. CC BY 4.0 License.

(c) (i)

6.4.0.43 tools. The validation of the cleaned data was finally done by qualified hydrographers. The produced data were finally reported to the IGN69 altimetry reference frame and to the Lambert 93 projection by the Circe Batch (V4-3, Using RAF09 model) conversion tool.

\subsubsection{Shom's bathymetric database}

Complementary bathymetric data used to generate the TBDTMs were extracted from the Shom's bathymetric database (BDBS).

They originate from 52 hydrographic surveys ( 490 millions of soundings) conducted between 1829 and 2019 with different sounding methods (lead-lines, single beam and multibeam echosounders). Spatial coverage of each survey is represented as a vector polygon layer (called hereafter bounding polygon) that may adjoin, overlap or supersede older hydrographic surveys. Each survey extracted from the BDBS is associated with metadata, including the acquisition and processing methods, the order survey and the quality of the data.

\subsubsection{Other data}

In addition to these bathymetric data, a bathymetric survey of the inner harbor delivered by the harbor authority of Saint-Malo was used in the present study. The bathymetric survey was carried out in June 2016 by the GEOXYZ society with a multibeam echosounder. Soundings were vertically referenced to the chart datum of Saint-Malo. This bathymetric source was evaluated prior to integration to other datasets.

The RGE ALTI ${ }^{\circledR}$ V2.0, produced by IGN, was exclusively used for the terrestrial domain. The data are available on the IGN's data portal (https://geoservices.ign.fr) in the RGF93 geodetic system, Lambert 93 projection. Vertical datum of the data corresponds to the NGF-IGN69 legal system (IGN, 2018). The RGE ALTI® v2.0 products used in the TBDTMs cover the departments of Côtes d'Armor, Ille et Vilaine and Manche at a resolution of $5 \mathrm{~m}$. Data was clipped with a buffer extending to $3 \mathrm{~km}$ inland. Water-surface values were also eliminated using the raster layer of sources provided with the DTMs.

\subsection{Production process}

\subsubsection{Convert data to a common horizontal and vertical datum}

The key requirement for creating a seamless merged product is the homogeneity of the input datasets in terms of horizontal and vertical datum (Gesch and Wilson, 2001). The vertical transformation to the ellipsoid was performed with Circe 5.1 France (IGN) and Bathyelli V2.0 (Shom) for topographic and bathymetric data, respectively.

\subsubsection{Conflict resolution}

Selecting the most reliable source from multi-temporal and multi-sensor data is a fundamental challenge addressed in numerous works (Macnab and Jakobsson, 2000; Wong et al., 2007; Maspataud et al., 2015). This issue is particularly true for hydrographic offices, whose data legacy may be substantial: Shom's hydrographic knowledge counts presently more than 10,000 bathymetric surveys conducted between 1816 and 2019 with many areas characterized by overlapping surveys. Survey depth measurements 
were collected with different sounding methods and positioning systems whose accuracy has improved over time. Moreover, the data may span decades, introducing temporal and geomorphologic change as a source of error (Eakins et al., 2011)

To date, the selection of the most reliable surveys (i.e. conflict resolution) for the production of nautical charts or TBDTMs was performed manually. This step is particularly time-consuming, especially in regularly surveyed areas (Maspataud et al., 2015). In order to limit this fastidious work, Shom initiated in 2019 the constitution of a bathymetric reference layer (Figure 2). The conflict resolution of overlapping surveys is executed using the attributes of survey acquisition date and survey status, the latter one defining if a survey supersede or complete older ones (Figure 2.b). In case of a survey with a "supersede" status, the deconfliction process is executed by clipping the bounding polygon of the reference survey to all other older overlapping surveys. No clipping is done for surveys with a "complete" status (Figure 2.b). The resulting layer, called "Téthys", is intended to represent the most relevant Shom's bathymetric knowledge available and will be regularly updated on the basis of newly integrated surveys (Figure 2.c). This reference layer will be of benefit to numerous Shom's activities.

The generation of TBDTMs in the Normand-Breton gulf benefited from the reliability of all metadata and bounding polygons in the area of interest, which constitute the preliminary step prior to the construction of the Téthys. The deconfliction process was executed on all datasets used for the generation of the TBDTMs using a semi-automated procedure based on GMT routines. For the datasets not integrated in the BDBS for which no status exists, this one was directly defined by the operator on the basis of inherent criteria of the data. The result of the deconfliction process corresponds to the most reliable soundings that can be used as input into the surface modeling.

\subsubsection{Interpolation}

Because multiple sources of data contribute to the construction of the DTM, some datasets have data point spacing larger than the required cell size. Splines functions are generally used for their efficiency to honour variable density data providing a representative smooth and continuous surface. They may be more appropriate for large interpolation distances, which is frequently required for bathymetric data (Amante (2012) and references therein). Based on these observations, Shom used the SAGA (System for Automated Geoscientific Analyses; Conrad et al. (2015)) software packages for the generation of the TBDTMs. Multilevel B-splines interpolation tool was used to perform surface modelling of the compiled data.

\subsubsection{Altimetric conversion grids}

Following NOAA's previous works (Eakins and Taylor, 2010; Eakins et al., 2011), different datum altimetric grids were developed by Shom to convert the TBDTMs from the ellipsoid to other tidal datums (Lowest Astronomical Tide and Mean Sea Level).

\subsubsection{Evaluation}

DTM coherency is evaluated based on visual inspection (slope, cross-section and 3D views), through additional layers (density, sources diagram) and, if possible, the cross-validation of the DTM using datasets that have not been incorporated into the gener- 


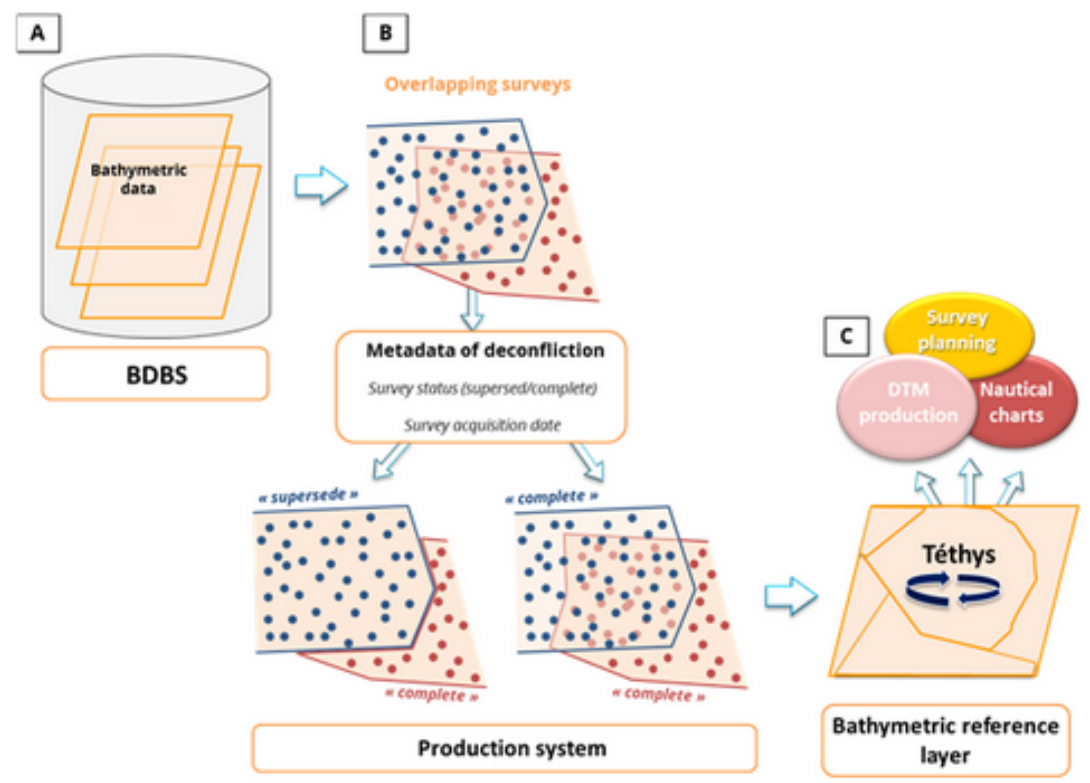

Figure 2. Workflow of Shom's bathymetric reference layer (« Téthys »). (A) Shom's hydrographic knowledge is composed of numerous overlapping surveys that are compiled in the BDBS. (B) In the case of overlapping surveys, a conflict resolution is applied based on the metadata of deconfliction. For bathymetric surveys which supersede older ones, the bounding polygon is used to clip the data. For bathymetric surveys which complete older ones, no action is performed. (C) Deconflicted data are compiled in one bathymetric reference layer for different applications. The reference layer will be updated each time a new survey is integrated in the BDBS.

ated product due to diffusion constraints. Despite the processing efforts and the deconfliction process, erroneous representation of the sea-floor may remain. Preliminary versions of the TBDTMs highlighted two different types of artifacts:

- the overlapping of some bathymetric surveys with a "complete" status, which lead to a noisy representation of the seafloor. For this type of problem, the status of identified extracted surveys was modified by the operator to generate a smooth surface.

- Oscillation effects characterized by edge effects or topographic creep generated by spline interpolation into unsurveyed marine areas (Eakins and Grothe, 2014; Danielson et al., 2016). These unwanted surface artefacts can be reduced by using locally an appropriate tension factor.

As long as anomalies are detected, their cause must be determined and data reprocessed prior to a new interpolation. These different steps must be repeated iteratively until a satisfactory result is reached (Eakins and Taylor, 2010). 

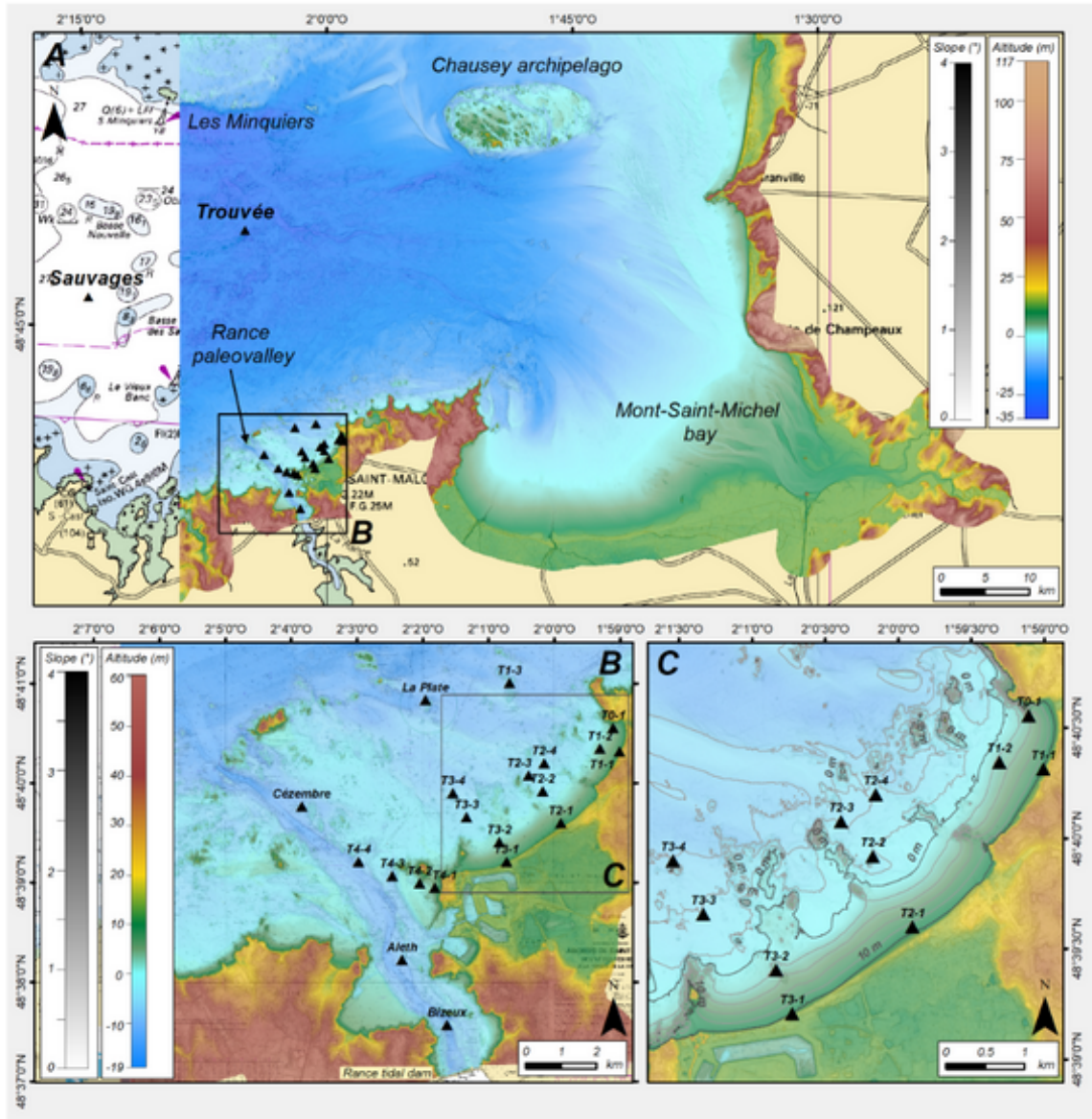

Figure 3. Nautical charts of Saint-Malo bay and its surroundings (@Shom). (A) coastal TBDTM covering a part of the Normand-Breton gulf at a resolution of $0.0002^{\circ}$ ( 20 m and moorings positions); (B) coastal TBDTM of the harbor of Saint-Malo and its surroundings at a resolution of $0.00005^{\circ}(\sim 5 \mathrm{~m})$ moorings positions. (C) Zoom on the sensors transects.

\section{Oceanographic dataset}

The oceanographic dataset includes water levels, currents and sea states observations from extensive oceanographic surveys conducted by Shom during winter 2018-2019. These data are monitored from different sensors types. These following sections describe the oceanographic surveys and data processing.

\subsection{Oceanographic Surveys}

From October 2018 to April 2019, an extensive oceanographic campaign was conducted in Saint-Malo bay. The campaign includes 22 moorings, each mooring contains one or two sensors, for a total of 37 sensors : 
https://doi.org/10.5194/essd-2021-316

Preprint. Discussion started: 1 October 2021

(c) Author(s) 2021. CC BY 4.0 License.

(c) (i)

- Two directional waveriders (Datawell, DWR-MkIII, hereafter referred to as Datawell)

- Two tide pressure gauges (Seabird Electronics, SBE26+, hereafter referred to as SBE)

- Four acoustic wave and current profilers (Nortek, AWAC $600 \mathrm{kHz}$, hereafter referred to as AWAC)

- Four single-point current meters (Nortek, Aquadopp single-point current meter, hereafter referred to as Aquadopp)

- Seven current profilers (Nortek, Aquadopp profiler $1 \mathrm{MHz}$, hereafter referred to as AquaPro)

- Eighteen wave pressure gauges (Ocean Sensor System Inc., ten OSSI-010-003C and eight OSSI-010-022, hereafter referred to as OSSI and OSSI-NEW, respectively)

The moorings were located to accurately describe hydrodynamic conditions from offshore to the coastline (Figure 3). The Datawell were deployed offshore at $25 \mathrm{~m}$ water depth (Sauvages and Trouvée, Figure 3.a), providing information on the incident wave fields. Other moorings were essentially deployed along four cross shore transects (T1, T2, T3 and T4, figure 3.b). Around the transects T1, T2 and T3, the beach profile is characterized by a gentle foreshore slope $\left(1.1-1.2^{\circ}\right.$, Figure 3.c). It increases slightly $\left(1.6^{\circ}\right)$ on the eastern part of the Minihic beach (T0 sensor). Transect T4 is located in the vicinity of the Grand Bé islet and is characterized by high slope variations due to the presence of the Rance estuary (Figure 3.b). Two moorings, with OSSI and AquaPro, were deployed in the Rance estuary (Bizeux and Aleth Figure 3.b). Table 1 summarizes the location of each mooring and sensor. For consistency with TBDTMs, the vertical datum used is the Lowest Astronomical Tide (LAT).

\subsubsection{Sensor settings}

Sensors deployed during the campaign have been programmed to accurately record the oceanographic data, taking into account battery and data storage limitations. Sensors settings in terms of measurement data, sampling rate, average interval and measurement interval are summarized for each sensor in Table 2.

\subsubsection{Sensor acquisition}

Figure 4 presents a summary report of sensor acquisition. All moorings, except buoys, started on 12 November 2018. The last acquisitions were around 30 March or 20 April for foreshore or offshore moorings, respectively. The acquisitions of Datawell buoys began on November 15, 2018, for Trouvée mooring and on December 2, 2018, for the Sauvages mooring, until April 29, 2019, for both buoys. Figure 5 shows interruptions in data acquisition for OSSI-NEW in transects T2 and T3. These interruptions were caused by less efficient batteries than anticipated on the OSSI-NEW's (as mentioned in table 2). For moorings on the foreshore, a brief interruption in the data acquisition appeared from 22/01/2019 to 24/01/2019. This interruption was planned for a battery change. The "La Plate" AWAC sensor did not acquire any data during the campaign (the sensor power cable was disconnected). For the T3-4 mooring, no data was recovered because the mooring was unrecovered by the scuba divers; the mooring had probably been stolen. Despite these incidents, the density and complementarity of the instruments used during the campaign allow us to have a description of the hydrodynamics in Saint-Malo bay. The data collection covers a winter period of more than 4 months. 
https://doi.org/10.5194/essd-2021-316

Preprint. Discussion started: 1 October 2021

(c) Author(s) 2021. CC BY 4.0 License.

(c) (1)

Table 1. Moorings and sensors location.

\begin{tabular}{|c|c|c|c|c|c|}
\hline Moorings & Sensors & Latitude (WGS84) & Longitude (WGS84) & Sensors depth (LAT) & Heightfrombed \\
\hline T0-1 & OSSI & $48.675893^{\circ}$ & $-1.985119^{\circ}$ & $-4.60 \mathrm{~m}$ & $0.19 \mathrm{~m}$ \\
\hline $\mathrm{T} 1-1$ & OSSI & $48.671880^{\circ}$ & -1.983443 & $-10.58 \mathrm{~m}$ & $0.15 \mathrm{~m}$ \\
\hline \multirow{2}{*}{$\mathrm{T} 1-2$} & OSSI & \multirow{2}{*}{$48.672397^{\circ}$} & \multirow{2}{*}{$-1.988447^{\circ}$} & $-3.98 \mathrm{~m}$ & $0.35 \mathrm{~m}$ \\
\hline & AquaDopp & & & $-4.34 \mathrm{~m}$ & $0.71 \mathrm{~m}$ \\
\hline \multirow{2}{*}{$\mathrm{T} 1-3$} & OSSI & \multirow{2}{*}{$48.683417^{\circ}$} & \multirow{2}{*}{$-2.011383^{\circ}$} & $6,00 \mathrm{~m}$ & $0.32 \mathrm{~m}$ \\
\hline & AWAC & & & $5.70 \mathrm{~m}$ & $0.62 \mathrm{~m}$ \\
\hline $\mathrm{T} 2-1$ & OSSI & $48.659966^{\circ}$ & $-1.998369^{\circ}$ & $-9.17 \mathrm{~m}$ & $0.11 \mathrm{~m}$ \\
\hline \multirow{2}{*}{$\mathrm{T} 2-2$} & OSSI & \multirow{2}{*}{$4.665283^{\circ}$} & \multirow{2}{*}{$-2.002883^{\circ}$} & $1.88 \mathrm{~m}$ & $0.35 \mathrm{~m}$ \\
\hline & AquaDopp & & & $1.52 \mathrm{~m}$ & $0.71 \mathrm{~m}$ \\
\hline \multirow{2}{*}{$\mathrm{T} 2-3$} & OSSI & \multirow{2}{*}{$48.667900^{\circ}$} & \multirow{2}{*}{$-2.006517^{\circ}$} & $4.09 \mathrm{~m}$ & $0.35 \mathrm{~m}$ \\
\hline & AquaPro & & & $3.73 \mathrm{~m}$ & $0.71 \mathrm{~m}$ \\
\hline \multirow{2}{*}{$\mathrm{T} 2-4$} & OSSI & \multirow{2}{*}{$48.669933^{\circ}$} & \multirow{2}{*}{$-2.002533^{\circ}$} & $4.72 \mathrm{~m}$ & $0.35 \mathrm{~m}$ \\
\hline & AquaPro & & & $4.36 \mathrm{~m}$ & $0.71 \mathrm{~m}$ \\
\hline T3-1 & OSSI & $48.653437^{\circ}$ & $-2.012057^{\circ}$ & $-11.36 \mathrm{~m}$ & - \\
\hline \multirow{2}{*}{ T3-2 } & OSSI & \multirow{2}{*}{$48.656722^{\circ}$} & \multirow{2}{*}{$-2.013924^{\circ}$} & $-3.67 \mathrm{~m}$ & $0.35 \mathrm{~m}$ \\
\hline & AquaDopp & & & $-4.03 \mathrm{~m}$ & $0.71 \mathrm{~m}$ \\
\hline \multirow{2}{*}{ T3-3 } & OSSI & \multirow{2}{*}{$48.660933^{\circ}$} & \multirow{2}{*}{$-2.022233^{\circ}$} & $4.16 \mathrm{~m}$ & $0.35 \mathrm{~m}$ \\
\hline & AquaPro & & & $3.80 \mathrm{~m}$ & $0.71 \mathrm{~m}$ \\
\hline \multirow{2}{*}{ T3-4 } & OSSI & \multirow{2}{*}{$48.664967^{\circ}$} & \multirow{2}{*}{$-2.025683^{\circ}$} & $4.96 \mathrm{~m}$ & $0.35 \mathrm{~m}$ \\
\hline & AquaPro & & & $4.60 \mathrm{~m}$ & $0.71 \mathrm{~m}$ \\
\hline T4-1 & OSSI & $48.649110^{\circ}$ & $-2.030283^{\circ}$ & $-5.93 \mathrm{~m}$ & $0.20 \mathrm{~m}$ \\
\hline \multirow{2}{*}{$\mathrm{T} 4-2$} & OSSI & \multirow{2}{*}{$48.649900^{\circ}$} & \multirow{2}{*}{$-2.034132^{\circ}$} & $-4.60 \mathrm{~m}$ & $0.35 \mathrm{~m}$ \\
\hline & AquaDopp & & & $-4.96 \mathrm{~m}$ & $0.71 \mathrm{~m}$ \\
\hline Tu? & OSSI & 40651170 & (2) & $5.26 \mathrm{~m}$ & $0.35 \mathrm{~m}$ \\
\hline $14-5$ & AquaPro & $40.05111 /$ & -2.041030 & $4.90 \mathrm{~m}$ & $0.71 \mathrm{~m}$ \\
\hline T4 4 & OSSI & 486534830 & 20406000 & $5.77 \mathrm{~m}$ & $0.35 \mathrm{~m}$ \\
\hline $14-4$ & AWAC & 40.053403 & -2.049000 & $5.50 \mathrm{~m}$ & $0.62 \mathrm{~m}$ \\
\hline Alot & OSSI & 180270220 & 20206170 & $4.46 \mathrm{~m}$ & $0.35 \mathrm{~m}$ \\
\hline AletII & AquaPro & $40.03 / 035$ & -2.030017 & $4.10 \mathrm{~m}$ & $0.71 \mathrm{~m}$ \\
\hline Di & OSSI & 406261670 & 0 & $9.36 \mathrm{~m}$ & $0.35 \mathrm{~m}$ \\
\hline Bizeux & AquaPro & $48.02010 /$ & $-2.02 / 150$ & $9.00 \mathrm{~m}$ & $0.71 \mathrm{~m}$ \\
\hline$C^{\prime}{ }^{\prime}$ & Marégraphe & 18667000 & 20620230 & $6.00 \mathrm{~m}$ & - \\
\hline Cezemore & AWAC & 40.002700 & -2.005953 & $5.90 \mathrm{~m}$ & $0.62 \mathrm{~m}$ \\
\hline $\mathrm{I}_{0} \mathrm{Dl}$ & Marégraphe & 106005230 & 20375030 & $5.17 \mathrm{~m}$ & - \\
\hline La Prate & AWAC & 48.080535 & -2.052585 & $6.20 \mathrm{~m}$ & $0.62 \mathrm{~m}$ \\
\hline Trouvée & DATAWELL & $48.813183^{\circ}$ & $-2.083483^{\circ}$ & $25 \mathrm{~m}$ & - \\
\hline Sauvages & DATAWELL & $48.768550^{\circ}$ & $-2.242817^{\circ}$ & $25 \mathrm{~m}$ & - \\
\hline
\end{tabular}

\subsection{Data processing}

210 The technical processes involved in generating the oceanographic dataset are as follows: 


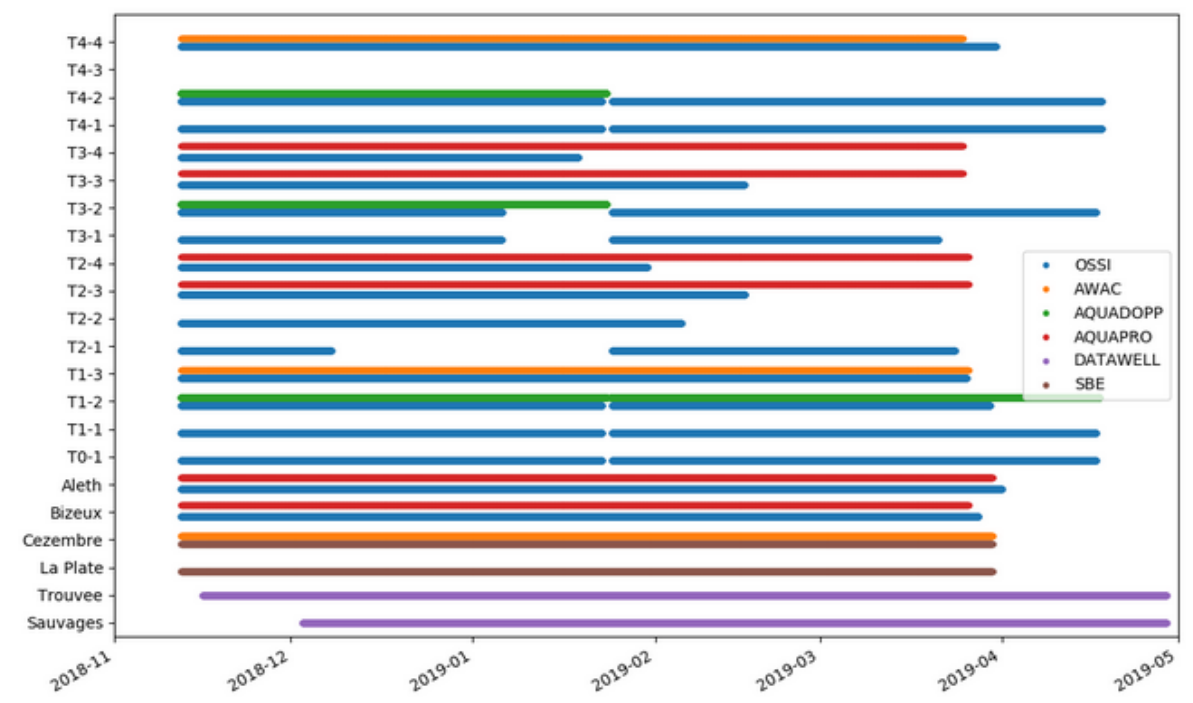

Figure 4. Moorings acquisition report.

- Pre-process binary data using the manufacturers' software.

- Process the data using manufacturers' software, Shom software (TDB) and Python toolbox developed for this study.

- Write data, metadata to netcdf format.

\subsubsection{Water levels}

215 The water levels are monitored by pressure sensors, tide pressure gauge (SBE) and wave pressure gauge (OSSI). These sensors record bottom pressure at different frequencies, bursts and intervals of acquisition (Table 2).

The tide Pressure gauges record the average bottom pressure every 20 minutes with a 2-min burst. First, the raw tide data file was extracted in ascii format with the seaterm manufacturer software (Seabird). Then, the raw data was processed by the TDB software. The raw data was converted in water level assuming hydrostatic equilibrium (Eq. 1). Finally, the processed data was subjected to final validation by a qualified hydrographer.

$h=\frac{P_{m}-P_{a t m}}{\rho g}$

with $P_{m}$ the bottom pressure measurement in Pa, $P_{a t m}$ the atmospheric pressure extracted from ERA5 atmospheric reanalysis in Pa, $\rho=1026 \mathrm{kgm}^{-3}$ the averaged water density measured in Saint-Malo bay and $g=9.81 \mathrm{~ms}^{-2}$ the gravitational acceleration.

The wave pressure gauges record bottom pressure at high frequency. The bottom pressure was directly recorded in ascii format. First, the raw pressure data of each sensor is calibrated using the pressure slope and offset of the sensor. For foreshore 
sensors, the pressure sensor was calibrated by comparing the pressure measured when the sensor is out of water to atmospheric pressure. For offshore sensors, the pressure sensor was calibrated at the end of the recording when the instrument was taken out of the water or in the laboratory. Then, the corrected pressure was converted into water level assuming hydrostatic equilibrium (Eq. 1). Finally, to reconstruct water level for the long waves such as tide, the water level was smoothed, with moving average of $10 \mathrm{~min}$, to filter out deformations of water surface related to short waves.

In order to be able to compare water levels recorded from different instruments, they have been relocated in height with respect to the tide gauge of Saint-Malo harbour. The correction factors (slope and offset) from Saint-Malo tide gauge is provided in the dataset for each sensor. The accuracy of water levels is in the order of $\pm 5 \mathrm{~cm}$. For consistency with TBDTMs, the vertical datum used is the Lowest Astronomical Tide (LAT).

\subsubsection{Currents}

The currents are monitored by acoustic Doppler current, single point current meters (Aquadopp) and profiler current meters (AquaPro and AWAC). These sensors record the speeds in the axis of their three beams. The raw binary data file was directly processed by the TDB software. First, the velocity data are reprojected in a terrestrial landmark, on the north-east-vertical axes. Then, measurements close to the surface and polluted by the secondary lobes of the acoustic beams are suppressed. The processed data was subjected to final validation by a qualified hydrographer. Prior to their deployment, the magnetic compasses of these current meters were previously calibrated on a dedicated Shom platform. The calibration procedure and the uncertainty of current data are described in Menn and Morvan (2020). Finally the current data and metadata of each sensor are written in netcdf format.

\subsubsection{Sea States}

The sea states are monitored by three different sensor types, directional wave buoy, wave pressure gauge, and acoustic wave and current profiler. Each sensor type requires specific processing.

The directional wave buoys recorded wave motion in three directions. The raw displacement datas were computed directly aboard the buoys. First, the buoy's displacement measurements were low-pass and high-pass filtered to give the threedimensional buoy motion in the frequency range of $0.01-0.64 \mathrm{~Hz}$. Then, the spectral data were computed from heaven-northwest displacements. Finally, the statistical wave parameters were computed using spectral data. A quality control based on skewness and kurtosis of vertical displacement were carried out. A 30-minutes data burst with $\mid$ Skewness $\mid>0.3$ and Kurtosis $>5$ have been marked with a quality control flag $(\mathrm{QC}=0)$.

The wave pressure gauges are used in part 3.2.1 to monitor the water level through hydrostatic equilibrium. The hydrostatic equilibrium is not enough for short wave monitors because short waves distort the surface elevation by non-hydrostatic effects (wave motion and roller structure as described in Martins et al. (2020)). The non-hydrostatic pressure signal related to the wave motion (dynamic pressure) is not entirely measured. The bottom pressure is attenuated exponentially with depth. Therefore, specific methodology must be applied to reconstruct the short wave-induced surface elevation. A recent review of Mouragues et al. (2019) provides different methods to reconstruct the short wave elevation from bottom pressure measurements. The free 
https://doi.org/10.5194/essd-2021-316

Preprint. Discussion started: 1 October 2021

(c) Author(s) 2021. CC BY 4.0 License.

(c) (i)

surface elevation related to the roller cannot be reconstructed by these methods. On this dataset, we use three different reconstruction methods : hydrostatic method, linear method and non linear weakly dispersive method (e.g Supplementary materials A.1). The pressure records were separated in a 20-min burst, each burst was linearly detrended to suppress tidal motion. The reconstruction methods were applied to reconstruct the surface elevation. Statistical wave parameters were computed by spectral analysis and wave-by-wave analysis (e.g Supplementary materials A.2).

The acoustic waves and currents profiler record surface elevation from Acoustic Surface Tracking (AST) and current in wave cells at high frequency. The raw data is directly processed using the Quickwave manufacturer software. High-frequency surface elevation combined with current measurements allow the reconstruction of a directional wave spectrum using SUV method (Pedersen et al., 2005). Directional and non directional bulk wave parameters were computed using directional wave spectrum for the band between $0.025-0.5 \mathrm{~Hz}$.

\section{Overview of oceanographic processes}

The figure 5 (A-C) shows an overview of the temporal evolution of the metocean conditions during the oceanographic field experiment.

During this experiment, several low-pressure systems affected Saint-Malo. These storm events produced skew surges from $22 \mathrm{~cm}$ to $61 \mathrm{~cm}$ and offshore significant wave heights from $2.29 \mathrm{~m}$ to $4.28 \mathrm{~m}$. These storms occur principally during neap tides. No coastal flooding was observed during this experiment. The storm's events and two major spring tide have been reported in Table 3 with the associated metocean conditions.

The wave transformation induces further processes affecting water level elevation such as wave set-up and infragravity wave (Dodet et al., 2018). The figure 5.D shows the wave set-up measurement (between sensor T1-1 and T1-2) and infragravity significant waves height (between 0,004 and 0,04 Hz) at T1-1. The maximum wave set-up was measured during the 09/12/18, 27/01/2019 and 10/06/19 storms with wave set-up measurement of $27 \mathrm{~cm}, 32 \mathrm{~cm}$ and $24 \mathrm{~cm}$, respectively. The maximum infragravity significant waves height also occur during these storms with heights greater than $50 \mathrm{~cm}$. The table 3 indicates the wave set-up, short and infragravity significant waves height at T1-1 for each storm and spring tide event.

The figure 6 shows the wave set-up measurement (between sensor T1-1 and T1-2) versus the offshore significant wave height. The wave set-up increases with the offshore significant wave height as expected. The water level play a major role in the evolution of this wave process. The highest wave set-up are observed at rising and falling tide. At high tide (sea levels $>12$ $\mathrm{m})$, the observed wave set-up is $10 \mathrm{~cm}$ for offshore waves of $4 \mathrm{~m}$.

\section{Data availability}

The TBDTMs (SHOM, 2020a, b) and oceanographic datasets (SHOM, 2021) are freely available at doi :

- https://doi.org/10.17183/MNT_COTIER_GNB_PAPI_SM_20m_WGS84 

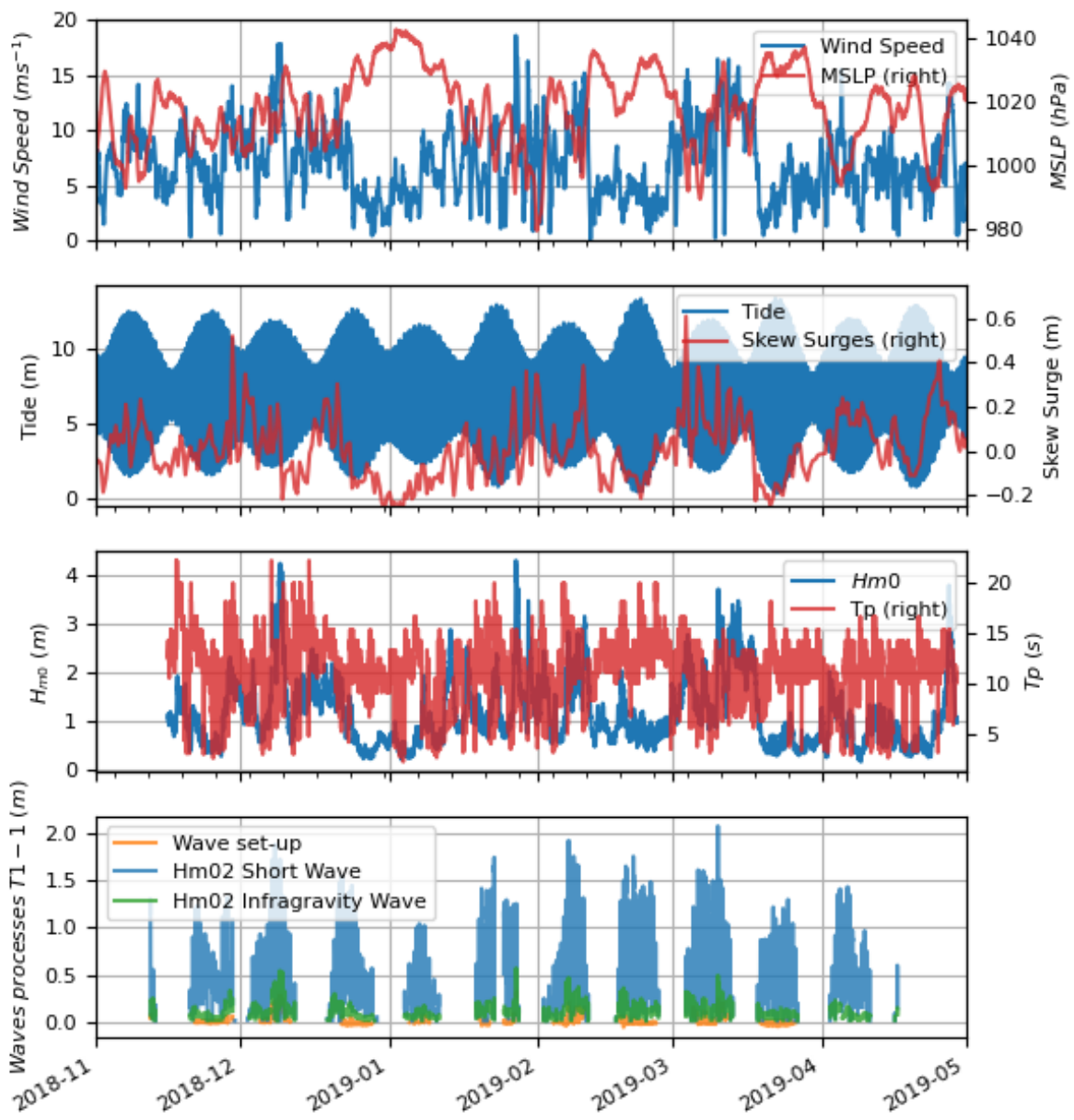

Figure 5. (A) wind speed and Mean Sea Level Pressure (MSLP) from ERA5 reanalysis in Saint-Malo. (B) Tide prediction and skew surge at Saint-Malo harbour tide gauge. (C) Significant wave height and peak period at Trouvée buoy. (D) Short and infragravity significant waves height, and wave set-up at T1-1 .

- https://doi.org/10.17183/CAMPAGNE_OCEANO_STMALO

TBDTMs is released through pre-packed files, including:

- files containing bathymetric surfaces, vertically referenced to different vertical datums (Mean Sea Level or Lowest Astronomical Tide) and converted in four grid formats, including NetCDF format (.grd by GMT), Bathymetric Attributed Grid (.bag), ESRI ASCII Raster format (.asc) and ascii text format (.glz)

- a metadata file that contains data sources, geographical extent, legal constraints and a brief summary of the building process, meeting the requirements of the INSPIRE Directive; 
https://doi.org/10.5194/essd-2021-316

Preprint. Discussion started: 1 October 2021

(c) Author(s) 2021. CC BY 4.0 License.

(c) (i)

\section{Water level $(m)$}

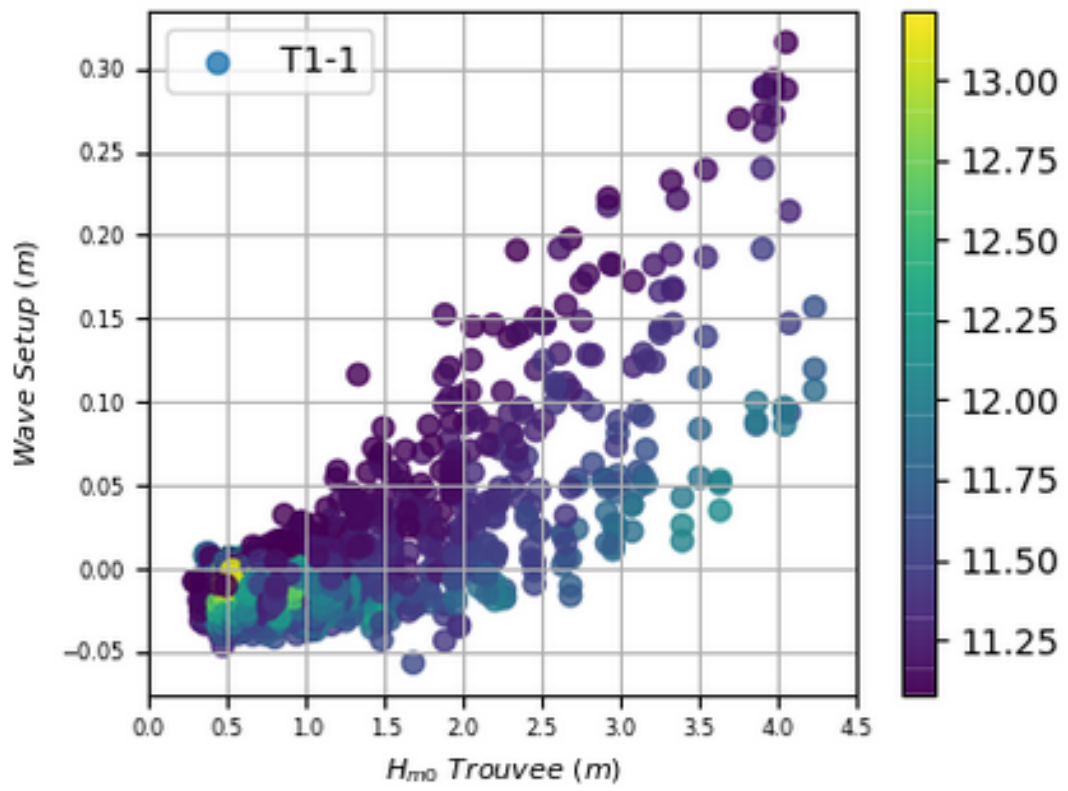

Figure 6. Wave set-up at T1-1 mooring according to offshore significant wave height and water level (color).

- the citation and an associated Digital Object Identifier (unique identifier used to cite scientific articles and datasets) to easily identify the future multiple uses of the DTM;

- the rights and contents report describing the main features of the product and its limitation of use.

Oceanographic dataset is available through three levels of processing, including :

- L0 : direct output of sensors at binary or ascii format.

- L1 : pre-processed data using the manufacturers' software at ascii format.

- L2 : processed data and metadata at NetCDF format.

The oceanographic dataset was plotted for a visual quality check and is available as "quick looks" on the repository.

\section{Conclusions}

The acquisition of new topo-bathymetric data in the Bay of Saint-Malo allowed the creation of a topo-bathymetric dataset. This dataset contains two TBDTMs with a resolution of $20 \mathrm{~m}$ and $5 \mathrm{~m}$, respectively. An extensive oceanographic campaign was also 
carried out to create a dataset that provides a set of oceanographic parameters (water levels, currents and sea states) in the Bay of Saint-Malo for different atmospheric, tidal and sea states conditions.

During the oceanographic campaign, three moderate storms occurred in the Bay of Saint-Malo. The dataset allows the evaluation of the different oceanographic processes involved in coastal flooding. This dataset provides, for the first time, a measurement of the wave transformation in the bay of Saint-Malo. It also provides a quantification of the wave processes at the foot of the protection structures. In this macro-tidal area, the variation of the water level plays a major role on wave processes. At high spring tide, the short and the infragravity waves spread up to the protection structures. The wave set-up is not established, but overtopping by sea pack can occur (not measured).

Topo-bathymetric and oceanographic datasets can be used to build, validate and calibrate hydrodynamic models. In particular, offshore wave measurements can be useful to force local high resolution models or validate spectral low resolution wave models. Thus, the long series of measurements in Saint-Malo bay will allow validating the models.

Despite the increasing number of satellites monitoring coastal variables at stake in flood risks, this type of datasets, even if costly and limited in space and time, allows the characterization of processes on a shorter scale, and remains necessary and complementary to discontinuous and not very accurate satellite datasets in coastal areas.

\section{Appendix A}

\section{A1 Surface elevation reconstruction method from bottom pressure}

On this dataset we use three different reconstruction methods:

(i) the hydrostatic reconstruction based on hydrostatic equilibrium (Eq. A1).

$$
\zeta_{h}=h-h_{0}+\delta_{m}
$$

with $\zeta_{h}$ the hydrostatic water level in $\mathrm{m}, h 0$ the mean water depth in $\mathrm{m}, \delta_{m}$ the sensor's distance from bed in $\mathrm{m}$.

(ii) The linear reconstruction based on a transfer function (Eq. A2) is the most commonly used method (Bishop and Donelan, 1987). This method consists of reconstructing surface wave elevation from linear wave theory.

$F\left[\zeta_{\text {linear }}\right]=K_{p}(\omega) F\left[\zeta_{h}\right]$

with $F[$.$] is the Fourier transform and K_{p}(\omega)$ the correction factor:

$$
K_{p}(\omega)=\frac{\cosh \left(k(\omega) h_{0}\right)}{\cosh \left(k(\omega) \delta_{m}\right)}
$$

Solving this equation requires the use of the dispersion relation of linear wave theory:

$$
\omega^{2}=\operatorname{gktanh}\left(k h_{0}\right)
$$


The use of the linear dispersive relationship (Eq A4.), to solve the linear reconstruction method, induce an overestimation of the correction factor at relatively high frequencies (typically $f>4 f_{p}$, with $f_{p}$ the peak frequency) as described in Bonneton and Lannes (2017); Bonneton et al. (2018); Mouragues et al. (2019); Martins et al. (2020). To solve this problem, the most commonly used method is to introduce a cut-off frequency. For frequencies exceeding the limit frequency, the correction factor can be replaced by different values : $\mathrm{Kp}=1$ (sharp cut-off, the linear spectrum is replaced by hydrostatic spectrum), linear correction factor, steady correction factor and Jonswap spectrum (see Mouragues et al. (2019) for description of these methods). The optimization of cut-off frequency and correction factor are a source of improvement in the representation of the wave shape (Mouragues et al., 2019; Martins et al., 2020). In this study, in order to simplify the treatment and make it homogeneous, a sharp cut-off frequency of $0.25 \mathrm{~Hz}$ was chosen for the whole dataset.

(iii) The nonlinear weakly dispersive (swnl) reconstruction (Eq. A5) was introduced by Bonneton and Lannes (2017); Bonneton et al. (2018). This method consists of reconstructing surface wave elevation from non-linear wave theory for weakly dispersive waves.

$\zeta_{s w n l}=\zeta_{s w l}-\frac{1}{g}\left(\partial_{t}\left(\zeta_{s w l} \partial_{t} \zeta_{s w l}\right)-\left(\frac{\delta_{m}}{h_{0}}\right)^{2}\left(\partial_{t} \zeta_{s w l}\right)^{2}\right)$

with $\zeta_{s w l}$ the free surface elevation by linear weakly dispersive reconstruction :

$\zeta_{s w l}=\zeta_{h}-\frac{h_{0}}{2 g}\left(1-\left(\frac{\delta_{m}}{h_{0}}\right)^{2}\right) \partial_{t}^{2} \zeta_{h}$

To solve this equation, we use the Fourier transform. Contrary to the linear method, the resolution of Eq.A5 does not require the use of a dispersion relationship. However, this transform requires intrusion of cutoff frequency to filter the measurement noise (Mouragues et al., 2019). In this study, in order to simplify the treatment and make it homogeneous, a cut-off frequency of $0.5 \mathrm{~Hz}$ was chosen for the whole dataset. This method allows a better reconstruction of the height of the highest waves near the breaking point (Mouragues et al., 2019), however its application is limited to a weakly dispersive wave regime.

\section{A2 Spectral and wave-by-wave analysis}

The statistical wave parameters were computed by a spectral analysis and a wave-by-wave analysis:

(i) The surface elevation PSD was computed for each burst using Welch's method (Hanning window and 50\% overlapped segments of 2048 samples). The significant wave height $\left(H_{m 0}\right)$ and others bulk parameters $\left(T_{m 01}, T_{m 02}\right)$ were computed using spectral moments:

$$
m_{p}=\int_{f_{\min }}^{f_{\max }} f^{p} E(f) d f
$$


https://doi.org/10.5194/essd-2021-316

Preprint. Discussion started: 1 October 2021

(c) Author(s) 2021. CC BY 4.0 License.

with $E(f)$ the wave energy spectra and $\left(f_{\min }, f_{\max }\right)$ the bandwidth. In this study $f_{\min }=0.025 \mathrm{~Hz}$ and $f_{\max }=0.5 \mathrm{~Hz}$ and,

$H_{m 0}=4 m_{0}$

$T_{m_{0, p}}=\left(m_{0, p}\right)^{-1 / p}$

The peak period was computed from the spectral maximum at the peak frequency $f_{p}$, as $T_{p}=1 / f_{p}$.

(ii) The wave-by-wave analysis was performed for each burst using a local maxima or peak to peak analysis. The positions between two consecutive crests (with distance $>2 \mathrm{~s}$ and amplitude $>0.1 \mathrm{~m}$ ) have been extracted to computed wave parameters. The maximum wave height and other bulk parameters $\left(H_{\text {mean }}, H_{\text {sig }}, T_{\text {mean }}\right)$ were computed using crests and troughs (minimum between two crests) :

$H=A_{\text {crest }}-A_{\text {trough }}$

375

$T=\left(P_{(\text {trough }, 1)}-P_{(\text {trough }, 0)}\right)\left(\frac{1}{f_{s}}\right)$

with $H$ the wave height, $T$ the wave period, $A_{\text {crest }}$ and $A_{\text {trough }}$ the crest and trough amplitude and,

$H_{\max }=\operatorname{Max}(H)$

$H_{\text {mean }}=\operatorname{Mean}(H)$

$H_{\text {sig }}=\operatorname{Mean}\left(H_{1 / 3}\right)$

$T_{\text {mean }}=\operatorname{Mean}(T)$

Author contributions. HM, LB, AP and FL designed the field experiments. LB produced the TBDTMs. LS produced the oceanographic dataset. LS and LB prepared the paper, with contributions from all co-authors.

Competing interests. The authors declare that they have no conflict of interest. 
https://doi.org/10.5194/essd-2021-316

Preprint. Discussion started: 1 October 2021

(c) Author(s) 2021. CC BY 4.0 License.

(c) (1)

Acknowledgements. The authors would like to thank the Shom GHOA, IES and Altimétrie littorale teams and all those who participated in the measurement campaign. This research is supported by Shom, Saint-Malo, SMA, Departmental Council of Ille et Vilaine (CD35), Brittany region and the French State. This research is also supported by PROTEVS research program funded by DGA and conducted by Shom. The Litto3D coastal elevation model used for this study is co-produced by IGN and Shom. 
https://doi.org/10.5194/essd-2021-316

Preprint. Discussion started: 1 October 2021

(c) Author(s) 2021. CC BY 4.0 License.

(c) (i)

\section{References}

Amante, C. J.: Accuracy of interpolated bathymetric digital elevation models, Ph.D. thesis, University of Colorado at Boulder, 2012.

Ardhuin, F.: observation et modelisation numerique des etat de mer ou vers une description realiste de la surface marine incluant les deferlements., in: Annales hydrographiques, vol. 6, Service hydrographique et océanographique de la marine, 2010.

Bertin, X., Bruneau, N., Breilh, J.-F., Fortunato, A. B., and Karpytchev, M.: Importance of wave age and resonance in storm surges: The case Xynthia, Bay of Biscay, Ocean Modelling, 42, 16-30, 2012.

Biscara, L., Maspataud, A., and Schmitt, T.: Generation of bathymetric digital elevation models along French coasts: Coastal risk assessment, Hydro Int, 20, 26-29, 2016.

Bishop, C. T. and Donelan, M. A.: Measuring waves with pressure transducers, Coastal Engineering, 11, 309-328, https://doi.org/10.1016/0378-3839(87)90031-7, 1987.

Bonneton, P. and Lannes, D.: Recovering water wave elevation from pressure measurements, Journal of Fluid Mechanics, 833, 399-429, https://doi.org/10.1017/jfm.2017.666, 2017.

Bonneton, P., Lannes, D., Martins, K., and Michallet, H.: A nonlinear weakly dispersive method for recovering the elevation of irrotational surface waves from pressure measurements, Coastal Engineering, 138, 1-8, https://doi.org/10.1016/j.coastaleng.2018.04.005, 2018.

Conrad, O., Bechtel, B., Bock, M., Dietrich, H., Fischer, E., Gerlitz, L., Wehberg, J., Wichmann, V., and Böhner, J.: System for Automated Geoscientific Analyses (SAGA) v. 2.1.4, Geoscientific Model Development, 8, 1991-2007, https://doi.org/10.5194/gmd-8-1991-2015, 2015.

Danielson, J. J., Poppenga, S. K., Brock, J. C., Evans, G. A., Tyler, D. J., Gesch, D. B., Thatcher, C. A., and Barras, J. A.: Topobathymetric Elevation Model Development using a New Methodology: Coastal National Elevation Database, Journal of Coastal Research, 76, 75-89, https://doi.org/10.2112/si76-008, 2016.

Dodet, G., Leckler, F., Sous, D., Ardhuin, F., Filipot, J., and Suanez, S.: Wave Runup Over Steep Rocky Cliffs, Journal of Geophysical Research: Oceans, 123, 7185-7205, https://doi.org/10.1029/2018jc013967, 2018.

Dodet, G., Melet, A., Ardhuin, F., Bertin, X., Idier, D., and Almar, R.: The Contribution of Wind-Generated Waves to Coastal Sea-Level Changes, Surveys in Geophysics, 40, 1563-1601, https://doi.org/10.1007/s10712-019-09557-5, 2019.

Eakins, B. and Taylor, L.: Seamlessly integrating bathymetric and topographic data to support tsunami modeling and forecasting efforts, Ocean globe, pp. 37-56, 2010.

Eakins, B. W. and Grothe, P. R.: Challenges in Building Coastal Digital Elevation Models, Journal of Coastal Research, 297, 942-953, https://doi.org/10.2112/jcoastres-d-13-00192.1, 2014.

Eakins, B. W., Taylor, L. A., Carignan, K. S., and Kenny, M. R.: Advances in Coastal Digital Elevation Models, Eos, Transactions American Geophysical Union, 92, 149-150, https://doi.org/10.1029/2011eo180001, 2011.

Famin, V., Michon, L., and Bourhane, A.: The Comoros archipelago: a right-lateral transform boundary between the Somalia and Lwandle plates, Tectonophysics, 789, 228 539, https://doi.org/10.1016/j.tecto.2020.228539, 2020.

Filipot, J.-F., Roeber, V., Boutet, M., Ody, C., Lathuiliere, C., Louazel, S., Schmitt, T., Ardhuin, F., Lusven, A., Outré, M., et al.: Nearshore wave processes in the Iroise Sea: field measurements and modelling, in: Coastal Dynamics 2013-7th International Conference on Coastal Dynamics, http://www. coastaldynamics2013. fr/pdf_files/055_Filipot_Jean_Francois.pdf, pp.p-605, 2013. 
https://doi.org/10.5194/essd-2021-316

Preprint. Discussion started: 1 October 2021

(c) Author(s) 2021. CC BY 4.0 License.

(c) (i)

Furgerot, L., Poprawski, Y., Violet, M., Poizot, E., du Bois, P. B., Morillon, M., and Mear, Y.: High-resolution bathymetry of the Alderney Race and its geological and sedimentological description (Raz Blanchard, northwest France), Journal of Maps, 15, 708-718, https://doi.org/10.1080/17445647.2019.1657510, 2019.

Gesch, D. and Wilson, R.: Development of a Seamless Multisource Topographic/Bathymetric Elevation Model of Tampa Bay, Marine Technology Society Journal, 35, 58-64, https://doi.org/10.4031/002533201788058062, 2001.

Hébert, H., Abadie, S., Benoit, M., Créach, R., Frère, A., Gailler, A., Garzaglia, S., Hayashi, Y., Loevenbruck, A., Macary, O., et al.: Project TANDEM (Tsunamis in the Atlantic and the English ChaNnel: Definition of the Effects through numerical Modeling)(2014-2018): a French initiative to draw lessons from the Tohoku-oki tsunami on French coastal nuclear facilities, in: EGU General Assembly Conference Abstracts, p. 6421, 2014.

Jourdan, D., Paradis, D., Pasquet, A., Michaud, H., Baraille, R., Biscara, L., Dalphinet, A., and Ohl, P.: La phase-3 du projet HOMONIM : définition et contenu, in: XVIèmes Journées, Le Havre, Editions Paralia, https://doi.org/10.5150/jngcgc.2020.087, 2020.

Louvart, L. and Grateau, C.: The Litto3D project, in: Europe Oceans 2005, IEEE, https://doi.org/10.1109/oceanse.2005.1513237, 2005.

Macnab, R. and Jakobsson, M.: Something old, something new: compiling historic and contemporary data to construct regional bathymetric maps, with the Arctic Ocean as a case study, The International Hydrographic Review, 2000.

Martins, K., Bonneton, P., Mouragues, A., and Castelle, B.: Non-hydrostatic, Non-linear Processes in the Surf Zone, Journal of Geophysical Research: Oceans, 125, https://doi.org/10.1029/2019jc015521, 2020

Maspataud, A., Biscara, L., Hébert, H., Schmitt, T., and Créach, R.: Coastal Digital Elevation Models (DEMs) for tsunami hazard assessment on the French coasts, in: EGU General Assembly Conference Abstracts, p. 1590, 2015.

445 Melet, A., Teatini, P., Cozannet, G. L., Jamet, C., Conversi, A., Benveniste, J., and Almar, R.: Earth Observations for Monitoring Marine Coastal Hazards and Their Drivers, Surveys in Geophysics, 41, 1489-1534, https://doi.org/10.1007/s10712-020-09594-5, 2020.

Menn, M. L. and Morvan, S.: Velocity Calibration of Doppler Current Profiler Transducers, Journal of Marine Science and Engineering, 8 , 847, https://doi.org/10.3390/jmse8110847, 2020.

Mouragues, A., Bonneton, P., Lannes, D., Castelle, B., and Marieu, V.: Field data-based evaluation of methods for recovering surface wave elevation from pressure measurements, Coastal Engineering, 150, 147-159, https://doi.org/10.1016/j.coastaleng.2019.04.006, 2019.

Pastol, Y.: Use of Airborne LIDAR Bathymetry for Coastal Hydrographic Surveying: The French Experience, Journal of Coastal Research, 62, 6-18, https://doi.org/10.2112/si_62_2, 2011.

Pedersen, T., Lohrmann, A., and Krogstad, H. E.: Wave measurements from a subsurface platform, Proceedings WAVES $2005,2005$.

SHOM: MNT topo-bathymétrique côtier d'une partie du golfe normand-breton (PAPI Saint-Malo), https://doi.org/10.17183/MNT_COTIER_GNB_PAPI_SM_20M_WGS84, 2020a.

SHOM: MNT topo-bathymétrique côtier du port de Saint-Malo et de ses abords (PAPI Saint-Malo), https://doi.org/10.17183/MNT_COTIER_PORT_SM_PAPI_SM_5M_WGS84, 2020b.

SHOM: Sea cruise French Flooding Prevention Action Program of Saint-Malo, https://doi.org/10.17183/CAMPAGNE_OCEANO_STMALO, 2021.

460 Tawil, T. E., Guillou, N., Charpentier, J.-F., and Benbouzid, M.: On Tidal Current Velocity Vector Time Series Prediction: A Comparative Study for a French High Tidal Energy Potential Site, Journal of Marine Science and Engineering, 7, 46, https://doi.org/10.3390/jmse7020046, 2019. 
https://doi.org/10.5194/essd-2021-316

Preprint. Discussion started: 1 October 2021

(c) Author(s) 2021. CC BY 4.0 License.

(c) (1)

Tew-Kai, E., Quilfen, V., Cachera, M., and Boutet, M.: Dynamic Coastal-Shelf Seascapes to Support Marine Policies Using Operational Coastal Oceanography: The French Example, Journal of Marine Science and Engineering, 8, 585, https://doi.org/10.3390/jmse8080585, 2020.

Wong, A. M., Campagnoli, J. G., and Cole, M. A.: Assessing 155 Years of Hydrographic Survey Data for High Resolution Bathymetry Grids, in: OCEANS 2007, IEEE, https://doi.org/10.1109/oceans.2007.4449373, 2007.

Woodworth, P. L., Melet, A., Marcos, M., Ray, R. D., Wöppelmann, G., Sasaki, Y. N., Cirano, M., Hibbert, A., Huthnance, J. M., Monserrat, S., and Merrifield, M. A.: Forcing Factors Affecting Sea Level Changes at the Coast, Surveys in Geophysics, 40, 1351-1397, https://doi.org/10.1007/s10712-019-09531-1, 2019. 
Table 2. Sensor acquisition protocol.

\begin{tabular}{|c|c|c|c|c|c|c|}
\hline Moorings & Sensors & Datas & Sampling rate & Average interval & Measurement interval & Remarks \\
\hline T0-1 & OSSI & Bottom Pressure & $10 \mathrm{~Hz}$ & \multicolumn{2}{|c|}{ Continuous } & - \\
\hline T1-1 & OSSI & Bottom Pressure & $10 \mathrm{~Hz}$ & \multicolumn{2}{|c|}{ Continuous } & - \\
\hline \multirow{2}{*}{$\mathrm{T} 1-2$} & OSSI & Bottom Pressure & $10 \mathrm{~Hz}$ & \multicolumn{2}{|c|}{ Continuous } & - \\
\hline & AquaDopp & $\begin{array}{c}\text { Current } \\
\text { Bottom Pressure }\end{array}$ & - & $120 \mathrm{~s}$ & $600 \mathrm{~s}$ & - \\
\hline \multirow{4}{*}{$\mathrm{T} 1-3$} & OSSI & Bottom Pressure & $10 \mathrm{~Hz}$ & \multicolumn{2}{|c|}{ Continuous } & - \\
\hline & & Current & - & $120 \mathrm{~s}$ & $600 \mathrm{~s}$ & \\
\hline & AWAC & AST & $2 \mathrm{~Hz}$ & $1024 \mathrm{~s}$ & $7200 \mathrm{~s}$ & - \\
\hline & & Bottom Pressure & $2 \mathrm{~Hz}$ & $1024 \mathrm{~s}$ & $7200 \mathrm{~s}$ & \\
\hline $\mathrm{T} 2-1$ & OSSI & Bottom Pressure & $8 \mathrm{~Hz}$ & \multicolumn{2}{|c|}{ Continuous } & Battery Problem \\
\hline \multirow{2}{*}{$\mathrm{T} 2-2$} & OSSI & Bottom Pressure & $8 \mathrm{~Hz}$ & \multicolumn{2}{|c|}{ Continuous } & Battery Problem \\
\hline & AquaDopp & $\begin{array}{c}\text { Current } \\
\text { Bottom Pressure }\end{array}$ & - & $120 \mathrm{~s}$ & $600 \mathrm{~s}$ & - \\
\hline \multirow{2}{*}{$\mathrm{T} 2-3$} & OSSI & Bottom Pressure & $8 \mathrm{~Hz}$ & $1800 \mathrm{~s}$ & $3600 \mathrm{~s}$ & Battery Problem \\
\hline & AquaPro & $\begin{array}{c}\text { Current } \\
\text { Bottom Pressure }\end{array}$ & - & $120 \mathrm{~s}$ & $1200 \mathrm{~s}$ & - \\
\hline \multirow{2}{*}{$\mathrm{T} 2-4$} & OSSI & Bottom Pressure & $8 \mathrm{~Hz}$ & $1800 \mathrm{~s}$ & $3600 \mathrm{~s}$ & Battery Problem \\
\hline & AquaPro & $\begin{array}{c}\text { Current } \\
\text { Bottom Pressure }\end{array}$ & - & $120 \mathrm{~s}$ & $1200 \mathrm{~s}$ & - \\
\hline T3-1 & OSSI & Bottom Pressure & $8 \mathrm{~Hz}$ & \multicolumn{2}{|c|}{ Continuous } & Battery Problem \\
\hline \multirow{2}{*}{ T3-2 } & OSSI & Bottom Pressure & $8 \mathrm{~Hz}$ & \multicolumn{2}{|c|}{ Continuous } & Battery Problem \\
\hline & AquaDopp & $\begin{array}{c}\text { Current } \\
\text { Bottom Pressure }\end{array}$ & - & $120 \mathrm{~s}$ & $600 \mathrm{~s}$ & - \\
\hline \multirow{2}{*}{ T3-3 } & OSSI & Bottom Pressure & $8 \mathrm{~Hz}$ & $1800 \mathrm{~s}$ & $3600 \mathrm{~s}$ & Battery Problem \\
\hline & AquaPro & $\begin{array}{c}\text { Current } \\
\text { Bottom Pressure }\end{array}$ & - & $120 \mathrm{~s}$ & $1200 \mathrm{~s}$ & - \\
\hline \multirow{2}{*}{ T3-4 } & OSSI & Bottom Pressure & $8 \mathrm{~Hz}$ & $1800 \mathrm{~s}$ & $3600 \mathrm{~s}$ & Battery Problem \\
\hline & AquaPro & Bottom Pressure & - & $120 \mathrm{~s}$ & $1200 \mathrm{~s}$ & - \\
\hline T4-1 & OSSI & Bottom Pressure & $10 \mathrm{~Hz}$ & \multicolumn{2}{|c|}{ Continuous } & - \\
\hline \multirow{2}{*}{ T4-2 } & OSSI & Bottom Pressure & $10 \mathrm{~Hz}$ & \multicolumn{2}{|c|}{ Continuous } & - \\
\hline & AquaDopp & $\begin{array}{c}\text { Current } \\
\text { Bottom Pressure }\end{array}$ & & $120 \mathrm{~s}$ & $600 \mathrm{~s}$ & - \\
\hline $43^{3}$ & OSSI & Bottom Pressure & $10 \mathrm{~Hz}$ & $1800 \mathrm{~s}$ & $3600 \mathrm{~s}$ & Mooring \\
\hline $14-3$ & AquaPro & $\begin{array}{c}\text { Current } \\
\text { Bottom Pressure }\end{array}$ & & $120 \mathrm{~s}$ & $1200 \mathrm{~s}$ & Lost \\
\hline T4 4 & OSSI & Bottom Pressure & $10 \mathrm{~Hz}$ & $1800 \mathrm{~s}$ & $3600 \mathrm{~s}$ & - \\
\hline $14-4$ & & Current & - & $120 \mathrm{~s}$ & $600 \mathrm{~s}$ & \\
\hline & AWAC & AST & $2 \mathrm{~Hz}$ & $1024 \mathrm{~s}$ & $7200 \mathrm{~s}$ & - \\
\hline & & Bottom Pressure & $2 \mathrm{~Hz}$ & $1024 \mathrm{~s}$ & $7200 \mathrm{~s}$ & \\
\hline Aleth & OSSI & Bottom Pressure & $10 \mathrm{~Hz}$ & $1800 \mathrm{~s}$ & $3600 \mathrm{~s}$ & - \\
\hline & AquaPro & $\begin{array}{c}\text { Current } \\
\text { Bottom Pressure }\end{array}$ & - & $120 \mathrm{~s}$ & $1200 \mathrm{~s}$ & - \\
\hline Bizeux & OSSI & Bottom Pressure & $10 \mathrm{~Hz}$ & $1800 \mathrm{~s}$ & $3600 \mathrm{~s}$ & - \\
\hline Dizedx & AquaPro & $\begin{array}{c}\text { Current } \\
\text { Bottom Pressure }\end{array}$ & - & $120 \mathrm{~s}$ & $1200 \mathrm{~s}$ & - \\
\hline Cézembre & SBE & Bottom Pressure & $4 \mathrm{~Hz}$ & $120 \mathrm{~s}$ & $1200 \mathrm{~s}$ & - \\
\hline Cezembre & & Current & - & $120 \mathrm{~s}$ & $600 \mathrm{~s}$ & \\
\hline & AWAC & AST & $1 \mathrm{~Hz}$ & $1024 \mathrm{~s}$ & $3600 \mathrm{~s}$ & - \\
\hline & & Bottom Pressure & $1 \mathrm{~Hz}$ & $1024 \mathrm{~s}$ & $3600 \mathrm{~s}$ & \\
\hline I Plot & SBE & Bottom Pressure & $4 \mathrm{~Hz}$ & $120 \mathrm{~s}$ & $1200 \mathrm{~s}$ & - \\
\hline La Plate & & Current & - & $120 \mathrm{~s}$ & $600 \mathrm{~s}$ & \\
\hline & AWAC & AST & $2 \mathrm{~Hz}$ & $1024 \mathrm{~s}$ & $7200 \mathrm{~s}$ & Sensor disconnected \\
\hline & & Bottom Pressure & $2 \mathrm{~Hz}$ & $1024 \mathrm{~s}$ & $7200 \mathrm{~s}$ & \\
\hline Trouvée & DATAWELL & Displacement & $1.28 \mathrm{~Hz}$ & & ntinuous & - \\
\hline Sauvages & DATAWELL & Displacement & $1.28 \mathrm{~Hz}$ & & ntinuous & - \\
\hline
\end{tabular}


https://doi.org/10.5194/essd-2021-316

Preprint. Discussion started: 1 October 2021

(c) Author(s) 2021. CC BY 4.0 License.

Table 3. Inventory of metocean conditions and waves processes during storm events and major spring tide events of field experiment.

\begin{tabular}{lccccccccc}
\hline & $\begin{array}{c}\text { MSLP } \\
(\mathrm{hPa})\end{array}$ & $\begin{array}{c}\mathrm{U} \\
(\mathrm{m} / \mathrm{s})\end{array}$ & $\begin{array}{c}\text { Hm0 } \\
(\mathrm{m})\end{array}$ & $\begin{array}{c}\text { Tp } \\
(\mathrm{s})\end{array}$ & $\begin{array}{c}\text { Height Tide } \\
(\mathrm{m})\end{array}$ & $\begin{array}{c}\text { Skew Surge } \\
(\mathrm{cm})\end{array}$ & $\begin{array}{c}\text { Set-up } \\
(\mathrm{cm})\end{array}$ & $\begin{array}{c}\text { Short } \\
(\mathrm{cm})\end{array}$ & $\begin{array}{c}\text { Ingravity } \\
(\mathrm{cm})\end{array}$ \\
\hline $29 / 11 / 18$ & 1003 & 14 & 2.29 & 18 & 10.59 & 53 & 4 & 110 & 25 \\
$09 / 12 / 18$ & 1011 & 18 & 4.24 & 11 & 11.80 & 22 & 27 & 173 & 54 \\
$27 / 01 / 19$ & 991 & 18 & 4.28 & 11 & 10.91 & 29 & 32 & 128 & 52 \\
$10 / 02 / 19$ & 996 & 15 & 3.08 & 8 & 10.98 & 39 & 15 & 130 & 24 \\
$21 / 02 / 19$ & 1032 & 3 & 1.0 & 10 & 13.17 & -10 & 0 & 136 & 12 \\
$03 / 03 / 19$ & 994 & 15 & 2.75 & 14 & 10.01 & 61 & - & - & - \\
$10 / 03 / 19$ & 1011 & 16 & 3.73 & 11 & 11.70 & 33 & 24 & 207 & 50 \\
$22 / 03 / 19$ & 1030 & 4 & 0.7 & 14 & 13.33 & -15 & 0 & 82 & 6 \\
\hline
\end{tabular}

